\title{
Assessment for Growth and Yield of Coriander (Coriandrum sativum linn.) with Micronutrients
}

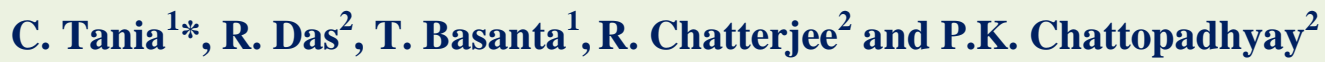 \\ ${ }^{1}$ ICAR RC NEH Region Manipur Centre, Imphal-795004, India \\ ${ }^{2}$ Department of Spices and Plantation Crops, Faculty of Horticulture, B. C. K. V., Mohanpur- \\ 741252, West Bengal, India \\ *Corresponding author
}

\begin{abstract}
A B S T R A C T
An experiment was conducted in RBD with 3 replications at Horticultural Research Station, BCKV, West Bengal to assess the influence of micronutrients with 12 treatments namely Boron $(0.02,0.05 \%)$, Zinc $(0.1,0.2 \%)$, B $-(0.02 \%+Z n-0.1 \%)$, B- $(0.02 \%+Z n-0.2 \%)$,

\section{Keywords}

Micronutrients, B

Zn, Growth, Yield,

Coriander

Article Info

Accepted:

04 November 2018

Available Online:

10 December 2018

B- $(0.05 \%+\mathrm{Zn}-0.1 \%), \mathrm{B}-(0.05 \%+\mathrm{Zn}-0.2 \%)$, Boron @ $1 \mathrm{~kg} / \mathrm{ha}$ (soil application), Zinc @ $5 \mathrm{~kg} / \mathrm{ha}$ (soil application), B@1kg/ha + Zn@ @kg/ha (soil application) and with control (water spray) on growth and yield of coriander (Local cultivar). Vegetative growth characters namely plant height $(75.10 \mathrm{~cm})$, root length $(9.94 \mathrm{~cm})$, number of primary (7.87) and secondary (19.13) branches, number of umbellets/umbel (5.73), number of seeds/umbellet (5.46), number of seeds/umbel (28.73), number of umbels/plant (29.40) recorded highest with B @ $0.02 \%+\mathrm{Zn} @ 0.1 \%$ treatment. The same treatment also recorded higher seed yield/ plant $(20.54 \mathrm{~g})$ and higher seed yield/ ha (16.54 q). Spraying with $\mathrm{B}-0.05 \%+\mathrm{Zn}-0.1 \%$, also proved effective with respect to growth characters namely root length $(9.65 \mathrm{~cm})$, number of primary (7.73) and secondary (17.87) branches, number of umbellets/umbel (5.66), number of seeds/umbel (28.20), and various yield components namely seed weight per umbellet $(0.063 \mathrm{~g})$ and seed weight/umbel $(0.35 \mathrm{~g})$. The results indicate that Boron and Zinc may be sprayed 45 days after sowing in coriander for better vegetative growth and yield at Gangetic plains of West Bengal.
\end{abstract}

\section{Introduction}

India, the land of spices grow about 52 spice crops in various parts of the country, among those a few number of crops are being grown commercially. Spices are being grown in about an area of 2.56 million hectares with the production of 0.27 million tones. During 2010-2011, the area under coriander in India has reached to 530.5 hectare with a production of 482.0 MT. (NHB database 2011).
Coriander (Coriandrum sativum. Linn) belongs to the family Apiaceae. It is an aromatic annual herbaceous plant. The cultivated area of seed spices was about $2,51,600$ ha with a production of $3,081,00$ tonnes during 1997-1998 (Ghosh et al., 2000). The main coriander growing states in India are Rajasthan, (40\% of total production in India), Uttar Pradesh, Chattisgarh, Punjab, Bihar, West Bengal, Andhra Pradesh, Tamil Nadu, Madhya Pradesh, Karnataka and Odisha. A 
dry and cold weather free from frost especially during flowering and fruit setting stage, favours good grain production. It thrives best in well drained sandy loam or clay loam soil in Terai and alluvial zone of West Bengal. The Indian soils are generally deficient in micronutrients especially zinc, boron, copper and molybdenum. West Bengal soils are mainly deficient in two important micronutrients (boron and zinc) for plant growth and development are boron and zinc. Keeping this in view two micronutrients (zinc and born) have been tried for obtaining higher yield of coriander.

\section{Materials and Methods}

The experiment was conducted at the Horticultural Research Station, Mondouri, B.C.K.V.,West Bengal during 2006-07 to evaluate the growth and yield of coriander with micronutrient. The site of the experiment is situated at $23.5^{\circ} \mathrm{N}$ latitude and $89^{\circ} \mathrm{E}$ longitude with an average altitude of $9.75 \mathrm{~m}$ above mean sea level. The soil of the experimental site is typical Gangetic alluvial soil (Entisol) having sandy loam texture, well drained with medium fertility status. The site where the experiment was carried out is under subtropical humid climate as it is situated just south of the Tropic of Cancer. The season of this region are broadly classified as Dry and Warm (March to May), Wet and Warm (June to October), Dry and Cool (November to February). In summer, temperature is high but the winter is short and mild. The crop was grown during the winter season. There were 12 treatments with 3 replications and 30 plots in a randomised block design (RBD) sown in $2^{\text {nd }}$ week of November. The spacing was 30 $\mathrm{cm}$ row to row and $10 \mathrm{~cm}$ plant to plant. The plot size was $2 \times 1.5 \mathrm{~m}$. A local cultivar's performance was assessed. The treatments were $\mathrm{T}_{1}-\mathrm{B} @ 0.02 \%, \mathrm{~T}_{2}-\mathrm{B} @ 0.05 \%, \mathrm{~T}_{3}-$ $\mathrm{Zn} @ 0.1 \%, \mathrm{~T}_{4}-\mathrm{Zn} @ 0.2 \%, \mathrm{~T}_{5}-\mathrm{B} @ 0.02 \%$ +Zn-0.1\%, $\mathrm{T}_{6}-\mathrm{B} @ 0.02 \%+\mathrm{Zn} @ 0.2 \%, \mathrm{~T}_{7}$
-B@0.05\%+Zn-0.1\%, T 8 - B @ 0.05\%+ $\mathrm{Zn}-0.2 \%, \mathrm{~T}_{9}-\mathrm{B} @ 1 \mathrm{~kg} / \mathrm{ha}$ (Soil application), $\mathrm{T}_{10}-\mathrm{Zn} @ 5 \mathrm{~kg} / \mathrm{ha}$ (Soil application), $\mathrm{T}_{11}$ - B @ $1 \mathrm{~kg} / \mathrm{ha}+\mathrm{Zn} @ 5 \mathrm{~kg} / \mathrm{ha}$ (Soil application), $\mathrm{T}_{12}$ - Water spray (control).

The growth regulators were sprayed 30 days after sowing and 15 days before flowering (50 DAS). Observations were recorded on plant height $(\mathrm{cm})$, root length $(\mathrm{cm})$, number of primary and secondary branches, number of umbels/plant, number of umbellets/umbel, seeds/umbellet, number of seeds/umbel, seed weight/umbellet $(\mathrm{g})$, seed weight/umbel $(\mathrm{g})$, seed yield/ plant (g), seed yield/plot (g) and seed yield/ha (q).

\section{Results and Discussion}

\section{Growth characters}

Plant height of coriander was found to vary between $75.10 \mathrm{~cm}$ and $60.08 \mathrm{~cm}$ due to different treatments. All the micronutrient treatments showed significant variation in plant height as compared to control treatment $(60.08 \mathrm{~cm})$. The plant height was in the order of $\quad \mathrm{T}_{5}>\mathrm{T}_{2}>\mathrm{T}_{4}>\mathrm{T}_{3}>\mathrm{T}_{1}>\mathrm{T}_{9}>\mathrm{T}_{8}>\mathrm{T}_{7}>\mathrm{T}_{9}>\mathrm{T}_{10}>\mathrm{T}_{11}$ $>\mathrm{T}_{12}$ (Table 1) length was measured in centimetre and was minimum with control treatment. Better influenced was recorded with both $\mathrm{T}_{5}(9.94 \mathrm{~cm})$ and $\mathrm{T}_{7}(9.65 \mathrm{~cm})$. Variation in root length amongst the treatments was also found to be significant (Table 1). The number of primary branches as recorded under the investigation was found to vary between 7.87 to 5.20 which was recorded higher with $\mathrm{T}_{5}$ (B @ $0.02 \%$ ) and the number was minimum under control. Similar to the number of primary branches, the number of secondary branches was also recorded highest with the same treatment B @ 0.02\% (19.13). The influence of micronutrients on production of primary and secondary branches was positive. The data presented in Table 1 indicates that the plants treated with Zn@ 0.5\% double 
spray produced (29.40) umbels/plant followed by $\mathrm{B}-0.2 \%+\mathrm{Zn}-0.5 \%$ single spray (28.40) and B @ $0.2 \%$ triple spray (28.13). The plants produced 5.73 number of umbellets/umbel with $\mathrm{T}_{5}$ treatment $\mathrm{Zn} @ 0.5 \%$ double spray) as against 3.87 umbellets/umbel in control. The variation within the treatment was significant in most of the treatments. Seed production per umbellets and number of seeds per umbel under the treatments were recorded highest (5.46 and 28.73 respectively) with the same treatment (Zn-0.5\% double spray) as was found with vegetative growth.

Table.1 Influence of micro-nutrients on growth of coriander

\begin{tabular}{|l|l|c|c|c|c|c|c|c|}
\hline Treatment & $\begin{array}{c}\text { Plant } \\
\text { height } \\
\text { (cm) }\end{array}$ & $\begin{array}{c}\text { Root } \\
\text { length } \\
(\mathbf{c m})\end{array}$ & $\begin{array}{c}\text { No. of } \\
\text { primary } \\
\text { branches }\end{array}$ & $\begin{array}{c}\text { No. of } \\
\text { secondary } \\
\text { branches }\end{array}$ & $\begin{array}{c}\text { No. of } \\
\text { Umblets/ } \\
\text { umbel }\end{array}$ & $\begin{array}{c}\text { No. of } \\
\text { seeds/ } \\
\text { umblet }\end{array}$ & $\begin{array}{c}\text { No. of } \\
\text { seeds/umbel }\end{array}$ & $\begin{array}{c}\text { No. of } \\
\text { umbels/plant }\end{array}$ \\
\hline $\mathrm{T}_{1}$ & 67.06 & 8.89 & 5.93 & 16.40 & 3.93 & 3.66 & 27.13 & 27.40 \\
\hline $\mathrm{T}_{2}$ & 70.70 & 9.08 & 5.80 & 17.13 & 4.93 & 4.13 & 27.47 & 27.67 \\
\hline $\mathrm{T}_{3}$ & 67.97 & 9.62 & 6.40 & 18.40 & 4.80 & 4.40 & 27.20 & 28.13 \\
\hline $\mathrm{T}_{4}$ & 70.69 & 8.87 & 7.00 & 17.13 & 4.86 & 4.46 & 27.07 & 26.60 \\
\hline $\mathrm{T}_{5}$ & 75.10 & 9.94 & 7.87 & 19.13 & 5.73 & 5.46 & 28.73 & 29.40 \\
\hline $\mathrm{T}_{6}$ & 64.16 & 9.23 & 6.33 & 17.27 & 4.93 & 4.53 & 27.73 & 27.60 \\
\hline $\mathrm{T}_{7}$ & 64.76 & 9.65 & 7.73 & 17.87 & 5.66 & 4.80 & 28.20 & 28.40 \\
\hline $\mathrm{T}_{8}$ & 65.65 & 8.74 & 5.73 & 17.33 & 4.73 & 4.26 & 27.33 & 26.73 \\
\hline $\mathrm{T}_{9}$ & 65.75 & 8.83 & 6.67 & 17.60 & 4.60 & 4.13 & 27.20 & 27.07 \\
\hline $\mathrm{T}_{10}$ & 64.17 & 8.74 & 6.53 & 17.20 & 4.80 & 4.40 & 27.73 & 27.47 \\
\hline $\mathrm{T}_{11}$ & 63.91 & 8.93 & 6.53 & 17.00 & 4.93 & 4.20 & 27.93 & 28.07 \\
\hline $\mathrm{T}_{12}$ & 60.08 & 8.37 & 5.20 & 15.93 & 3.87 & 3.46 & 25.27 & 25.46 \\
\hline $\mathrm{SE}_{\mathbf{n}} \pm$ & 0.18 & 0.02 & 0.04 & 0.04 & 0.03 & 0.02 & 0.04 & 0.05 \\
\hline $\mathrm{CD}$ & 0.59 & 0.07 & 0.12 & 0.12 & 0.08 & 0.08 & 0.12 & 0.15 \\
\hline
\end{tabular}

Table.2 Influence of micro-nutrients on yield of coriander

\begin{tabular}{|l|c|c|c|c|c|}
\hline Treatment & Seed weight/umbellet $(\mathrm{g})$ & Seed weight/umbel $(\mathrm{g})$ & Test weight $(\mathrm{g})$ & Seed yield/plot $(\mathrm{g})$ & Seed yield/ha $(\mathbf{q})$ \\
\hline $\mathrm{T}_{\mathbf{1}}$ & 0.045 & 0.33 & 12.79 & 460.43 & 13.04 \\
\hline $\mathrm{T}_{2}$ & 0.051 & 0.38 & 12.77 & 462.77 & 13.11 \\
\hline $\mathrm{T}_{3}$ & 0.053 & 0.33 & 13.45 & 466.05 & 13.07 \\
\hline $\mathrm{T}_{4}$ & 0.056 & 0.33 & 13.89 & 448.05 & 12.68 \\
\hline $\mathrm{T}_{5}$ & 0.063 & 0.35 & 12.75 & 490.75 & 14.06 \\
\hline $\mathrm{T}_{6}$ & 0.057 & 0.34 & 12.77 & 462.53 & 12.79 \\
\hline $\mathrm{T}_{7}$ & 0.057 & 0.31 & 12.74 & 463.07 & 13.30 \\
\hline $\mathrm{T}_{\mathbf{8}}$ & 0.052 & 0.34 & 12.40 & 449.77 & 12.74 \\
\hline $\mathrm{T}_{9}$ & 0.051 & 0.34 & 12.73 & 463.88 & 12.95 \\
\hline $\mathrm{T}_{10}$ & 0.055 & 0.34 & 12.80 & 473.37 & 13.18 \\
\hline $\mathrm{T}_{11}$ & 0.052 & 0.34 & 12.60 & 514.50 & 14.57 \\
\hline $\mathrm{T}_{\mathbf{1 2}}$ & 0.043 & 0.32 & 11.43 & 411.38 & 11.65 \\
\hline $\mathrm{SEm} \pm$ & 0.00025 & 0.00078 & 0.03 & 1.12 & 0.03 \\
\hline $\mathrm{CD}(\mathbf{5} \%)$ & 0.00079 & 0.00252 & 0.09 & 3.61 & 0.11 \\
\hline
\end{tabular}




\section{Yield characters}

The data presented in Table 2 depicts that yield attributing characters (seed weight/umbellets, seed weight/umbel, test weight, seed yield/plot and seed yield/ha) of coriander were also influenced by micronutrients at different concentrations. The plants treated with B@ 0.02\% + Zn@ $0.1 \% \quad\left(\mathrm{~T}_{5}\right)$ produced highest seed weight $(0.063 \mathrm{~g}) / \mathrm{umbellet}$. However the seed weight/umbel was recorded higher $(0.38 \mathrm{~g})$ with the seeds harvested from the plants treated with B@0.05\% $\left(\mathrm{T}_{2}\right)$ and the variation was recorded significant with the other treatments.

The $\mathrm{T}_{5}$ treatment $(\mathrm{B} @ 0.02 \%+\mathrm{Zn} @ 0.1 \%)$ also proved effective in producing higher seed weight per umbel $(0.35 \mathrm{~g})$. The seed weight/ umbel was similar $(0.34 \mathrm{~g})$ with the treatments $\mathrm{T}_{6}-\mathrm{B} @ 0.02 \%+\mathrm{Zn} @ 0.2 \%, \mathrm{~T}_{8}-$ B@0.05\% + Zn@0.2\%, B@1kg/ha (Soil application), Zinc@5kg/ha (soil application) and B @ $1 \mathrm{~kg} / \mathrm{ha}+\mathrm{Zn} @ \mathrm{~kg} / \mathrm{ha}$ (Soil application) and the treatments (B@0.02\%, $\mathrm{T}_{3}-\mathrm{Zn} @ 0.1 @$, and $\left.\mathrm{T}_{4}-\mathrm{Zn} @ 0.2 \%\right)$ registered $0.33 \mathrm{~g}$ seed weight/ umbel. The test weight registered higher with both $\mathrm{T}_{3}$ and $\mathrm{T}_{4}$ treatments (13.45 $\mathrm{g}$ and $13.89 \mathrm{~g}$ respectively). The Table 2 indicates maximum seed yield per plot $(514.50 \mathrm{~g})$ with $\mathrm{T}_{11}$ treatment $(\mathrm{B}$ @ $1 \mathrm{~kg} / \mathrm{ha}+\mathrm{Zn} @ 5 \mathrm{~kg} / \mathrm{ha}$ (soil application), followed by $\mathrm{T}_{5}$ treatment i.e. B@ $0.02 \%+\mathrm{Zn}$ @ $0.1 \%$ (490.75 g). The seed yield/plot was in the order of $\mathrm{T}_{11}>\mathrm{T}_{5}>\mathrm{T}_{10}>\mathrm{T}_{3}>\mathrm{T}_{9}>\mathrm{T}_{7}>\mathrm{T}_{2}>\mathrm{T}_{6}$ $>\mathrm{T}_{1}>\mathrm{T}_{8}>\mathrm{T}_{4}>\mathrm{T}_{12}$. Similar to other characters the seed yield/ha was also recorded highest with $\mathrm{T}_{11}$ treatment $(16.54 \mathrm{q})$. The seed yield/ha in the treatments $T_{7}, T_{10}$ and $T_{2}$ were also quite high $(15.65 \mathrm{q}, \quad 15.50 \mathrm{q}$ and $15.42 \mathrm{q}$ respectively). Higher seed yield/plant, seed yield/plot and seed yield/hectare were also reported by Udaya Kumar (2007) with combined application of B @ $0.02 \%$ and Zn @ $0.1 \%$.

In conclusion, the treatments with micronutrients (B and $\mathrm{Zn}$ ) at different concentrations showed greater influence on different growth characters and yield parameters as against the control i.e. with water spray. The study showed a significant contribution of Boron for the increase in growth and seed yield of coriander under alluvial soil of West Bengal, which is found economically feasible. The present investigation indicates treatment $\mathrm{T} 5$ and $\mathrm{T} 11$ may be recommended for achieving higher yield in coriander.

\section{References}

Anonymous (2006). www.indianspice.com Ghosh, S.P., Pal, R.N. Peter, K.V. and Ravindra, R.N. 2000. Four decades of spice Res. Dev. An over view. Indian Spice, 36: 11-17.

Udaya Kumar, J.N. 2007. Effect of Boron and Zinc on growth, yield and quality of fenugreek. M.Sc. Thesis submitted in Bidhan Chandra Krishi Viswavidyalaya Mohanpur, West Bengal.

\section{How to cite this article:}

Tania, C., R. Das, T. Basanta, R. Chatterjee and Chattopadhyay, P.K. 2018. Assessment for Growth and Yield of Coriander (Coriandrum sativum linn.) with Micronutrients. Int.J.Curr.Microbiol.App.Sci. 7(12): 336-339. doi: https://doi.org/10.20546/ijcmas.2018.712.041 